\title{
PERILAKU KOMUNIKASI WANITA SYIAH DALAM PERNIKAHAN MUT'AH
}

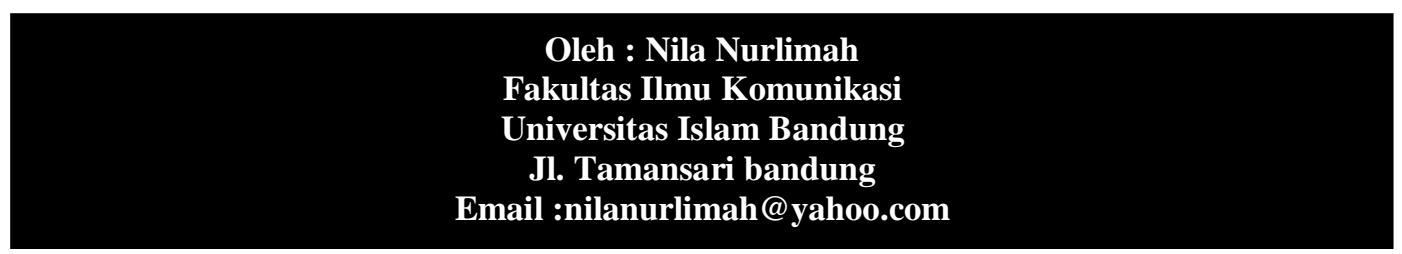

Abstract. This research was also intended to find out the communication behavior of the actors of mut'ah marriage to either their husbands or their surrounding communities. This research used the qualitative method by using the symbolic interaction approach The dramaturgical attitude in front of Sunni communities and mature attitude in doing the mut'ah marriage were the consequence of the marriage The results of the research show that, communication behavior of Syiah women that could be seen from two aspects, namely: 1) In the Polygamy Mut'ah actors, mut'ah of Sunni husband, and continuous mut'ah with different husband, the verbal communication used tended to be very careful with limited non-verbal communication, and the mediated communication as wished. Meanwhile, in the monogamy mut'ah, mut'ah without intimate course, mut'ah with Syiah husband, and continuous mut'ah with the same husband the verbal communication was very expressive with common non-verbal communication, and unlimited mediated communication.2) In the aspect of interaction to the environment, all mut'ah actors had opened attitude to the Syiah and closed attitude to the Sunni.

Key Word: communication behavior, mut'ah marriage, syi'ah women

Abstrak. Penelitian ini dimaksudkan untuk mengungkap perilaku komunikasi para pelaku nikah mut'ah baik dengan suami maupun dengan lingkungan sekitar.Penelitian dengan menggunaka pendekatan studi interaksi simbolik ini memperlihatkan adanya sikap dramaturgis di hadapan masyarakat Sunni dan sikap dewasa dalam menjalani pernikahan mut'ah, .Hasl penelitian menunjukkan bahwa pada pelaku mut'ah poligami, mut'ah suami Sunni, dan mut'ah berkali-kali dengan suami yang berbeda perilaku komunikasi verbal cenderung hati-hati, komuni kasi non verbal terbatas, dan komunikasi bermedia seperlunya. Sementara pada mut'ah monogami, mut'ah tanpa hubungan intim, mut'ah dengan suami Syi'ah, mut'ah berkali-kali dengan suami yang sama komunikasi verbal lebih ekspresif, komunikasi non verbal wajar, dan komunikasi bermedia leluasa. Pada aspek interaksi dengan lingkungan semua pelaku mut'ah bersikap sama terhadap lingkungan yaitu terbuka terhadap kalangan Syiah dan tertutup terhadap kalangan non Syiah.

Kata Kunci : perilaku komunikasi, wanita Syiah, nikah mut'ah

\section{A. PENDAhuluan}

Beragam bentuk perkawinan banyak ditemukan dalam kehidupan masyarakat. Salah satu pernikahan unik yang banyak dilakukan oleh kalangan Syiah adalah praktek nikah mut'ah. Nikah mut'ah adalah pernikahan yang dilakukan oleh seorang laki-laki dan seorang perempuan dalam jangka waktu tertentu. Nikah ini disebut juga dengan nikah Muaqqat atau nikah munqathi Disebut nikah mut'ah (mut'ah secara bahasa berarti bersenangsenang) karena laki-laki hendak bersenangsenang buat sementara waktu saja.

Meski mendapat kecaman keras dari kalangan mazhab Sunni, tetapi kalangan 
Syiah tetap meyakini kebenaran dan mempraktekkan perkawinan mut'ah, dengan segala konsekuensi yang harus dihadapi. Di kalangan penganut mazhab Syiah, praktek nikah mut'ah ini sudah biasa dilakukan, termasuk di Kota Bandung yang mayoritas masyarakatnya mengecam mut'ah sebagai prostitusi. Bagi mereka tidak ada perbedaan antara nikah mut'ah yang dibatasi waktu dengan nikah da'im yang permanen, keduanya samasama legal secara Islam.

Wanita pelaku nikah mut'ah memiliki sudut pandang yang berbeda dengan pandangan kaum wanita modern pada umumnya. Mereka meyakini tidak ada pacaran dalam Islam, maka mereka memilih nikah mut'ah sebagai nikah yang legal, dengan segala risiko dan rintangan yang harus dihadapi, baik dalam interaksi dan beradaptasi serta komunikasi dengan suami dalam waktu dan kondisi yang sangat terbatas, maupun dengan lingkungan sosial yang mengecam keras praktek mut'ah mereka, yang harus dihadapi dengan sabar, hati-hati dan penuh kedewasaan.

Realitas pengalaman yang dihadapi membangun skema kognitif yang unik. Keunikan ini terletak pada kesediaan mereka menjadi pasangan suami istri untuk sementara waktu. Mereka juga siap menghadapi masyarakat Sunni yang mengecam pernikahan mereka. Kecaman masyarakat telah memaksa mereka untuk berhati-hati dalam melaksanakan pernikahan mut'ah mereka. Mereka dituntut untuk memilih peran yang bisa diterima lingkungan.

Keputusan menikah mut'ah merupakan keputusan yang sangat individual. Pemaknaan yang unik pada perkawinan mut'ah akan memunculkan perilaku komunikasi yang unik pula. Bagaimana mereka memaknai pernikahan mut'ah? Bagaimana mereka membangun komunikasi dengan pasangan dan lingkungan yang mengecam? Tentu saja persoalan-persoalan tersebut demikian kompleks dan tidak sederhana, diperlukan eksplorasi mendalam untuk memahami semua pertanyaan ini.

Fokus penelitian ini adalah mengkaji secara komprehensif perilaku komunikasi pelaku nikah mut'ah di Kota Bandung. Untuk lebih mengurai fokus dalam penelitian maka dirumuskan pertanyaan penelitian sebagai berikut :

1. Bagaimana pelaksanaan nikah mut'ah pada perempuan kalangan Syiah ?

2. Bagaimana perilaku komunikasi wanita pelaku nikah mut'ah dengan suami dan lingkungannya?

Penelitian ini bermaksud untuk mengungkap dan menemukan bagaimana pelaksanaan nikah mut'ah mereka, serta memahami perilaku komunikasi yang 
Edutech, Tahun 12, Vol.1, No.3, Oktober 2013

dibangun para perempuan pelaku nikah mut'ah dengan suami maupun dengan lingkungannya. Adapun tujuan dari penelitian ini adalah :

1. Mengungkap dan menjelaskan pelaksanaan nikah mut'ah pada perempuan kalangan Syiah.

2. Menggali perilaku komunikasi wanita pelaku nikah mut'ah dengan suami dan lingkungannya.

Penelitian ini menggunakan pendekatan interaksi simbolik Teori interaksi simbolik dari Blumer mengacu pada 3 premis utama yaitu,; pertama, manusia bertindak pada sesuatu berdasarkan makna-makna yang ada pada sesuatu itu bagi mereka. Kedua, makna tersebut diperoleh suatu interaksi social yang dilakukan oleh orang lain. Ketiga, makna makna tersebut disempurnakan disaat proses interaksi sosial sedang berlangsung.

George Ritzer (Mulyana,2008) meringkas teori interaksi simbolik kedalam prinsip-prinsip sebagai berikut.

1. Manusia, tidak seperti manusia yang lebih rendah diberkati kemampuan untuk berpikir.

2. Kemampuan berpikir itu dibentuk oleh interaksi sosial.

3. Dalam interaksi sosial orang belajar makna dan symbol yang memungkinkan mereka menerapkkan kemampuan khas 
Proses pengumpulan data lapangan bersifat sekali jadi. Proses itu diulang dan analisis dalam penelitian ini beberapa kali hingga tingkat validitas dan berlangsung secara simultan dan interaktif reliabilitasnya memadai (jenuh). Proses itu (konfrontasi data bolak-balik) tidak digambarkan sebagai berikut :

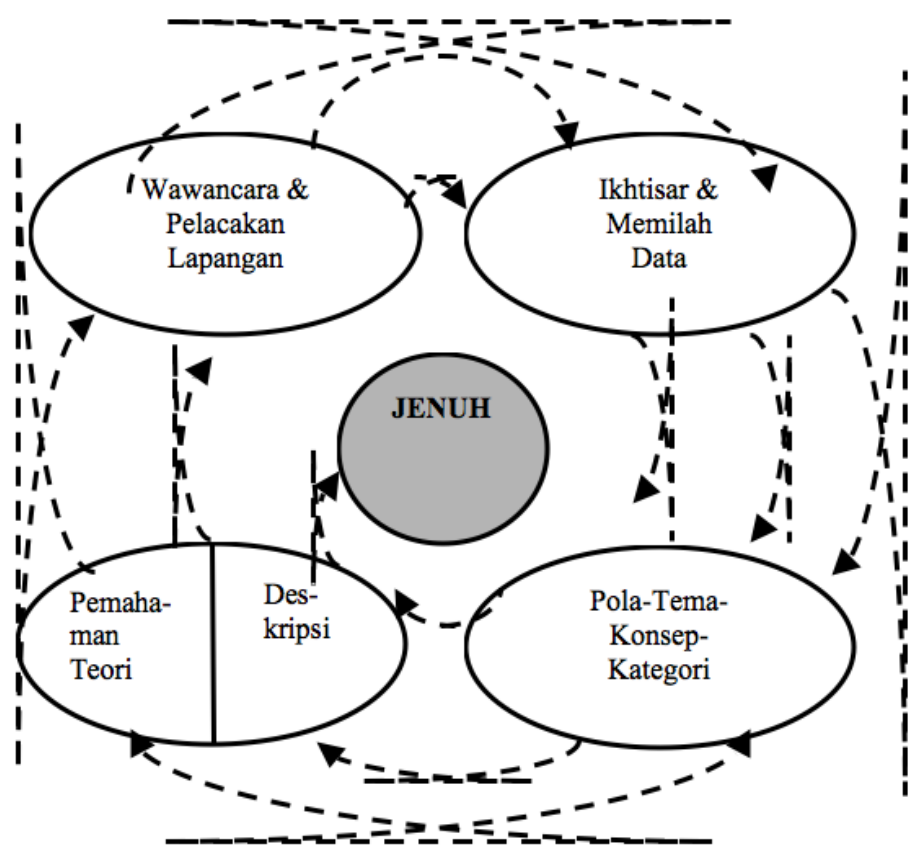

Gambar 2 Proses Pengumpulan Data. (Sumber : Hasil Penelitian, 2012)

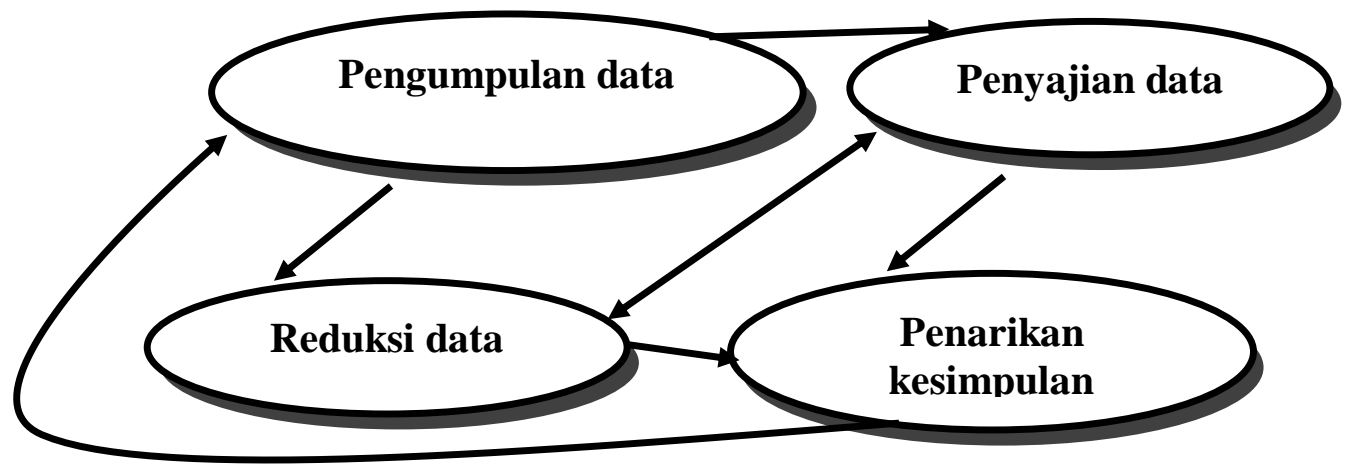

Gambar 3 Langkah Analisis Data Kualitatif, Model Interaktif (Sumber: Miles dan Huberman,1992)

Teknik analisis data yang Lincoln \& Guba yang dikutip dalam digunakan mengacu pada teknik yang Rachmat (2006). Tahapan-tahapan diperkenalkan oleh Glasser \& Strauss, 
analisisnya dapat dijelaskan sebagai berikut :

1. Menempatkan kejadian-kejadian (data) ke dalam kategori-kategori. Kategori-kategori harus dapat diperbandingkan satu dengan yang lainnya.

2. Memperluas kategori sehingga di dapat kategori data yang murni dan tidak tumpang tindih satu dengan yang lainnya.

3. Mencari hubungan antar kategori.

\section{B. HASIL DAN PEMBAHASAN}

1. Teori

Interaksionisme

\section{Simbolik}

Mead menolak anggapan bahwa seseorang bisa mengetahui siapa dirinya melalui introspeksi. Ia menyatakan bahwa untuk mengetahui siapa diri kita maka kita harus melukis potret diri kita melalui sapuan kuas yang datang dari proses taking the role of the other ---membayangkan apa yang dipikirkan orang lain tentang kita. Para interaksionis menyambut gambaran mental ini sebagai the looking glass self dan hal itu dikonstruksi secara sosial.

Penganut interaksionisme simbolik menyatakan bahwa self adalah fungsi dari bahasa. Tanpa pembicaraan tidak aka nada konsep diri, oleh karena itu untuk mengetahui siapa dirinya, seseorang harus menjadi anggota komunitas. Merujuk pada pendapat Mead self (diri) adalah proses mengkombinasi $I$ dan $m e . I$ adalah kekuatan spontan yang tidak dapat diprediksi. Ini adalah bagian dari diri yang tidak terorganisir. Sementara me adalah gambaran diri yang tampak dalam the looking-glass dari reaksi orang lain.

Me tidak pernah dilahirkan. Me hanya dapat dibentuk melalui interaksi simbolik yang terus menerus - mulai dari keluarga, teman bermain, sekolah, dan seterusnya. Oleh karena itulah seseorang membutuhkan komunitas untuk mendapatkan konsep dirinya. Seseorang membutuhkan the generalized other, yaitu berbagai hal (orang, obyek, atau peristiwa) yang mengarahkan bagaimana kita berpikir dan berinteraksi dalam komunitas. Me adalah organized community dalam diri seorang individu.

Perspektif interaksi simbolik memandang manusia dari sudut 
pandang subjek. Perspektif ini menyarankan bahwa perilaku manusia harus dilihat sebagai proses yang memungkinkan manusia membentuk dan mengatur perilaku mereka dengan mempertimbangkan ekspektasi orang lain yang menjadi mitra bagi interaksi mereka.

Mead menjelaskan proses interaksi simbolik terjadi dalam tiga unsur utama, yaitu pikiran (mind), diri (self) dan masyarakat (society) Ketiga unsur ini terkait satu sama lain . Ketika seseorang berinteraksi, sebenarnya pikiran yang sedang bekerja dengan memproduksi simbol dan mengartikan simbol yang diterima dari orang lain. Proses pertukaran dan interaksi ini tidak terlepas dari Konteks masyarakatnya tersebut.

Dalam penelitian ini, ingin menelaah tentang bagaimana pelaku nikah mut'ah memahami simbol-simbol verbal dan nonverbal, dan menentukan sikap berdasarkan pemaknaannya tersebut. Stigma masyarakat Sunni yang melekat pada perkawinan mereka akan berpengaruh terhadap pandangannya terhadap dirinya dan orang lain. Demikian juga simbol-simbol positif yang diperoleh dari lingkungan Syiah, akan berpengaruh terhadap keteguhan terhadap keyakinan legalitas perkawinannya. Dan pada gilirannya akan membentuk pola komunikasi yang unik antara pelaku nikah mut'ah dengan pasangan, lingkunan Syiah, dan lingkungan masyakat Sunni.

\section{Teori Dramaturgi}

Pendekatan dramaturgis

Goffman berintikan pandangan bahwa ketika manusia berinteraksi dengan sesamanya, ia ingin mengelola pesan yang ia harapkan tumbuh pada orang lain terhadapnya. Untuk itu, setiap orang melakukan pertunjukan bagi orang lain. Kaum dramaturgis memandang manusia sebagai aktor-aktor di atas panggung metaforis yang sedang memainkan peran-peran mereka.

Pengembangan dari Goffman tidak terlepas dari pengaruh gagasan Cooley tentang the looking glass self. Gagasan diri ala Cooley ini terdiri dari tiga komponan.Pertama, kita mengembangkan bagaimana kita 
tampil bagi orang lain; kedua, kta membayangkan bagaimana penilaian mreka atas penampilan kita; ketiga, kita mengembagkan sejenis perasaan diri, seperti kebanggaan atau malu, sebagai akibat membayangkan penilaian orang lain tersebut. Lewat imajinasi, kita mempersepsi dalam pikiran orang lain suatu gambaran tentang penampilan kita, perilaku, tujuan, perbuatan, karakter tmanteman ita dan sebagainya, dan dengan berbagai cara kita terpengaruh olehnya.

Konsep yang digunakan Goffman berasal dari gagasangagasan Burke, dengan demikian pendekatan dramaturgis sebagai salah satu varian interaksionisme simbolik yang sering menggunakan konsep "peran sosial" dalam menganalisis interaksi sosial, yang dipinjam dari khasanah teater. Peran adalah ekspektasi yang didefinisikan secara sosial yang dimainkan seseorang suatu situasi untuk memberikan citra tertentu kepada khalayak yang hadir. Bagaimana sang aktor berperilaku bergantung kepada peran sosialnya dalam situasi tertentu. Fokus dramaturgis bukan konsep-diri yang dibawa sang aktor dari situasi kesituasi lainnya atau keseluruhan jumlah pengalaman individu, melainkan diri yang tersituasikan secara sosial yang berkembang dan mengatur interaksi-interaksi spesifik. Menurut Goffman diri adalah "suatu hasil kerjasama" (collaborative manufacture) yang harus diproduksi baru dalam setiap peristiwa interaksi social.Goffman mengasumsikan bahwa ketika orang-orang berinteraksi,

Mereka ingin menyajikan suatu gambaran diri yang akan diterima orang lain. Ia menyebut upaya itu sebagai "pengelolaan pesan" (impression management), yaitu teknik-teknik yang digunakan aktor untuk memupuk kesan-kesan tertentu dalam situasi tertentu untuk mencapai tujuan tertentu.

Dalam perspektif dramaturgis, kehidupan ini ibarat teater, interaksi sosial yang mirip dengan pertunjukan di atas panggung, yang menampilkan peran-peran yang dimainkan para aktor. Untuk memainkan peran tersebut 
biasanya sang aktor menggunakan bahasa verbal dan menampilkan perilaku nonverbal tertentu serta mengenakan atribut-atribut tertentu, misalnya kendaraan, pakaian dan asesoris lainnya yang sesuai dengan perannya dalam situasi tertentu. Aktor harus memusatkan pikiran agar dia tidak keseleo lidah, menjaga kendali diri, melakukan gerak-gerik, menjaga nada suara dan mengekspresikan wajah yang sesuai dengan situasi.

Menurut Goffman kehidupan sosial itu dapat dibagi menjadi "wilayah depan" (front region) dan "wilayah belakang" (back region). Wilayah depan merujuk kepada peristiwa sosial yang menunjukkan bahwa individu bergaya atau menampilkan peran formalnya. Mereka sedang memainkan perannya di atas panggung sandiwara di hadapan khalayak penonton. Sebaliknya wilayah belakang merujuk kepada tempat dan peristiwa yang memungkinkannya mempersiapkan perannya di wilayah depan. Wilayah depan ibarat panggung sandiwara bagian depan (front stage) yang ditonton khalayak penonton, sedang wilayah belakang ibarat panggung sandiwara bagian belakang (back stage) atau kamar rias tempat pemain sandiwara bersantai, mempersiapkan diri, atau berlatih untuk memainkan perannya di panggung depan.

Pelaku nikah mut'ah dalam realisasi kehidupan masyarakat Indonesia yang mayoritas Sunni, telah mengalami stigma sosial, budaya, dan hukum. pernikahan mereka tidak diakui baik secara hukum agama (Islam Sunni), hukum negara, budaya dan sosial. Sebagaimana halnya stigmatisasi mazhab yang mereka anut, praktek nikah mut'ah yang dilegalkan oleh kalangan Syiah ini juga mengalami stigma. Praktek nikah mut'ah dianggap sebagai tindakan perzinahhan dan pelacuran. Pelaku nikah mut'ah dianggap sebagai pezinah. Kondisi ini menyebabkan mereka selalu berusaha merepresentasikan diri (front) di depan lingkungan masyarakat Sunni berdasarkan citra yang diinginkannya, dengan menyembunyikan pernikahan 
Edutech, Tahun 12, Vol.1, No.3, Oktober 2013

mereka. Hal ini dilakukan supaya terhindar dari stigma pelacur, pelaku zinah, dan wanita nakal. Melalui perspektif dramaturgi, akan dijelaskan bagaimana mereka mengelola kesan untuk menyembunyikan atau menampilan diri ketika berhadapan dengan lingkungan yang mengecam pernikahan mereka.

\section{Mut'ah dalam Pandangan}

\section{Sunni vs Syi'ah}

Masalah hukum nikah mut'ah ini selalu melahirkan perbedaanperbedaan pendapat yang prinsipil dan tajam antara ulama Sunni dan syi'ah itu sendiri. Para ulama Sunni memandang nikah mut'ah itu haram hukumnya buat selamalamanya meskipun dahulu pernah dibolehkan nabi karena pembolehan itu telah dinasakh buat sepanjang masa dengan ketentuan-ketentuan yang telah ditetapkan.

Bagi ulama Sunni, diantara dalil-dalil penasakh (penghilang) kebolehan nikah mut'ah itu:

a. Q.S. 23 Al-Mu'minun: 5-6, yaitu :
Dan orang-orang yang menjaga kemaluannya, Kecuali terhadap interi-isteri mereka atau budak yang mereka miliki [994\}; Maka Sesungguhnnya mereka dalam hal ini tidak tercela.

Menurut Sunni, dalam ayat ini disebutkan hanya ada dua orang, perempuan yang boleh dicampuri yaknik istri dan budak, sedangkan perempuan yang dimut'ah tidaklah tergolong dari salah satu dari keduanya. Pendapat ini, menurut satu riwayat, didasarkan pada pendapat Aisyah dan Qasyim bin Muhammad.

b. Ali r.a dan Ibnu Mas'ud mengatakan ayat 24 surah an-Nisa yang dijadikan syi'ah sebagai dalil kehalalan nikah mut'ah itu dinasakh (dirubah hukumnya) oleh ayat-ayat tentang thalaq, iddah, warisan.

Disamping itu ada juga ulamaulama Sunni yang menolak penafsiran ayat 24 surah an-Nisa 
(istamta'tu) yang ditafsirkan golongan syi'ah dengan nikah mut'ah. Ibnu Khuwaizi Mandad, misalnya mengatakan ayat: ayat itu tidaklah sesuai jika dikaitkan dengan kebolehan nikah mut'ah karena Rasul sendiri telah melarangnya dan lagi pula Allah SWT mengatakan Fankihu bi izni ahlihinna, yang mermakna nikah syar'I dengan wali dan 2 orang saksi, sedangkan nikah mut'ah tidaklah tergolong dalam hal ini. Demikian juga halnya dengan para penafsir lainnya seperti Ibnu Jarir ath-Thabari, al-Qurthubi, Sanqithi, Sa'id Hawa dan lain-lain tidak sepakat jika ayat itu diartikan dengan nikah mut'ah. Ath-Thabari mengartikan kata al-Istimta yang ada pada ayat itu dengan arti nikah secara umum (nikah shahih), bukan nikah mut'ah. Seperti yang diartikan oleh syi'ah.

Pendapat ulama-ulama tafsir Sunni yang mengharamkan nikah mut'ah ini (dalam Rusydi; 2007) juga tampak dari berbagai komentar-komentar mereka dalam berbagai tafsir yang ada dan sebagian mereka juga menyadarkan pendapat para sahabat. Misalnya lagi, azZamakhsyari mengatakan ayat itu (Qs.4:24) turun mengenai mut'ah ketika Makkah ditaklukkan. Mut'ah diizinkan 2 kali dan dilarang 2 kali, dan menurut pendapat beliau Ibnu Abbas pernah mengeluarkan fatwa tentang boleh mut'ah akan tetapi beliau sendiri telah mencabut dan bertaubat pada Allah swt tentang pernyataan beliau mengenai nikah Mut'ah itu. Ali as-Sais mengutip riwayat Malik dari Ali bahwa nabi saw melarang nikah mut'ah, demikian juga Umar melarangnya.

Hadis-hadis yang melarang mut'ah juga banyak diantaranya dalam Shahih Bukhori bab 38 tentang Maghazi (kusunya pada perang khaibar) dan bab Nikah, dalam Shahih Muslim bab Nikah (ada lebih kurang 11 hadis) Sunan Abi Daud bab 13 hadis no. 2072 dan 2073 disebut riwayat dari Rabi' bin Saburah dari 2 sanad yang berbeda bahwa rasul melarang nikah mut'ah pada masa haji wada. Dalam Sunan atTirmidzi pada bab 28 no. 1121 juga disebut satu hadis yang berasal dari Ali r.a bahwa nabi saw 
Edutech, Tahun 12, Vol.1, No.3, Oktober 2013

melarang nikah mut'ah pada masa khaibar, demikian juga pada Sunan an-Nasa'I bab 71 hadis no 3365, 3366, 3367 dan 3368 (semuanya berjumlah 4 hadis). 3 hadis pertama berasal dari Ali ra dan satu hadis terakhir berasal dari Rabi' bin Saburah yang menjelaskan tentang haramnya nikah mut'ah pada hari Khaibar.

Demikian juga halnya pendapat para Imam mazhab, baik Hanafi, Maliki, Syafi'I dan Hanbali serta jumhur sahabat dan tabi'in tetap mengharamkan nikah mut'ah.

Adapun alasan-alasan akal yang digunakan Sunni untuk mengharamkan nikah mut'ah ini seperti yang telah disinggung di atas diantaranya karena pada nikah mut'ah tidak ada warisan, tidak sabitnya (tetapnya) nasab dan tidak adanya iddah, nikah ini juga dianggap mirip dengan pelacuran di mana laki-laki memberikan bayaran untuk dapat bercampur (hanya memenuhi kebutuhan sahwat semata) dalam waktu yang ditentukan, merendahkan derajat perempuan, bertentangan dengan tujuan perkawinan yang ingin mendapatkan keturunan dan membina rumah tangga yang bahagia dalam jangka panjang (dunia-akhirat)..

Namun berbeda tajam dengan alasan-alasan di atas, para ulama syi'ah tetap membolehkan nikah mut'ah tanpa terkecuali dan kebolehannya berlaku sepanjang zaman. Dalili-dalil yang mereka gunakan dalam menentang pendapat Sunni dan membolehkan nikah mut'ah juga terdiri dari Alqur'an, hadis dan akal.

Dalil Alqur'an yang mereka gunakan yaitu Q.S. 4. An-Nisa' ayat 24. Ayat ini -menurut mereka- (dalam Rusydi; 2007) nyata-nyata berkenaan dengan nikah mut'ah dan pembolehannya. Mereka beralasan dengan pandapat/tafsir Ibnu Abbas tentang ayat ini dengan menambahkan kata Ilaajal al-musamma ${ }^{1}$ (Sampai waktu tertentu) sehingga bermakna nikah mut'ah' ${ }^{2}$ Mereka juga mengambil riwayat dari Ibnu 
Abbas (dalam Rusydi; 2007) yang mengatakan: "Tidaklah nikah mut'ah itu dihalalkan kecuali sebagai rahmat Allah swt kepada umat Muhammad saw, dan andainya Umar tidak melarangnya, maka tidaklah berzinah kecuali seseorang yang benar-benar celaka". Pendapat Ibnu Abbas ini diikuti oleh penduduk Makkah dan Yaman.

Mereka juga menolak pendapat Sunni yang menyatakan ayat itu telah dinasakh dengan alasan ayat-ayat penasakh itu adalah lebih dahulu turun dari ayat-ayat yang dinasakh, seperti surah al-Mu'minun ayat 5-6 itu adalah ayat Makkiyah yang lebih dahulu turun dari pada surah anNisa' ayat 24 (Madaniyah) yang berbicara tentang $m u t^{\prime} a h^{3}$.

Di samping itu (dalam Rusydi : 2007) mereka juga menolakhadis-hadis yang digunakan ulama Sunni dengan hadis-hadis shahih lainnya seperti hadis riwayat Bukhori-Muslim dari Ibnu Mas'ud yang berisi tentang pembolehan nikah mut'ah ketika para sahabat dalam keadaan perang. Nabi memberi rukhsoh (membolehkannya) kemudian Ibnu Mas'ud membacakan ayat: "Ya Ayyuha al-lazinah amanu la tuharrimu tayyiban ma ahallallahu lakum wala ta'tadu inna Allah la yuhibbu al-mu'tadin. (hai orangorang yang beriman jaganlah kamu mengharamkan hal-hal yang baik yang dihalalkan Allah pada kamu dan janganlah kamu melampaui batas karena Allah SWT tidak pernah mencintai orang-orang yang melampaui batas).

Demikian juga dalam riwayat Bukhori lainnya yang berasal dari Umrani bin Hushain yang mengatakan: Telah turun ayat tentang nikah mut'ah dalam Alqur'an dan kami telah melakukannya pada masa Rasullah dan tak satupun ayat yang melarang dan mengharamkankannya sampai rasul wafat.

Di samping itu syi'ah juga menganggap lemah dan menolak fatwa umar yang mengharamkan nikah $m u t$ 'ah. Mereka mengatakan hal itu hanya ijtihad dan ya'yunya 
saja. Menurut mereka nikah mut'ah masih halal dan diamalkan oleh sebagian sahabat sejak zaman nabi Abu Bakar, dan sebagaian masa Umar.

Adapun alasan yang akal dikemukakan ulama Sunni dibantah syia'ah dengan mengatakan; nikah mut'ah tidaklah merendahkan martabat perempuan, sebab laki-laki memberikan mahar padanya, bukan upah atau bayaran seperti yang terjadi pada pelacuran, mahar tidak bisa disamakan dengan upah, nasab anak tetap digantungkan kepada ayahnya, anak mempunyai hak waris dari kedua orang tuanya walaupun suami-istri tidak saling mewarisi. Bahkan Ja'far Murtadha al-Amili yang merupakan salah satu pemikir terkemuka dalam aliran syi'ah, juga mengatakan nikah mut'ah pada hakikatnya sama saja dengan nikah permanen, sebab syrat-syratnya sama, perbedaannya hanya terdapat pada batas waktu, tidak adanya keharusan memberi nafkah, tidak saling mewarisi dan adanya kehamilan ditetapkan menurut perjanjian bersama.

\section{Pelaksanaan Nikah Mut"Ah}

\section{a. Konflik dalam Nikah Mut'ah}

Dari data penelitian, didapatkan berbagai potensi konflik para informan sebagai berikut :

Tabel Potensi Konflik Nikah Mut'ah

\begin{tabular}{|c|l|c|c|c|c|c|c|c|}
\hline \multirow{2}{*}{ No } & \multicolumn{1}{|c|}{ Potensi Konflik } & \multicolumn{6}{|c|}{ Informan } \\
\cline { 3 - 9 } & & $\begin{array}{c}\text { Bula } \\
\mathrm{n}\end{array}$ & $\begin{array}{c}\text { Bin- } \\
\text { tang }\end{array}$ & $\begin{array}{c}\text { Pelan } \\
\text { gi }\end{array}$ & $\begin{array}{c}\text { Maw } \\
\text { ar }\end{array}$ & $\begin{array}{c}\text { Mela } \\
\text { ti }\end{array}$ & $\begin{array}{c}\text { Mata } \\
\text {-hari }\end{array}$ & $\begin{array}{c}\text { Anye } \\
\text {-lir }\end{array}$ \\
\hline 1 & Mut'ah tertutup & - & - & + & + & + & + & + \\
\hline 2 & $\begin{array}{l}\text { Tidak tinggal } \\
\text { serumah }\end{array}$ & - & - & + & + & + & + & + \\
\hline 3 & Pergaulan & + & + & + & + & + & + & + \\
\hline 4 & Hubungan seksual & - & - & + & + & + & + & + \\
\hline 5 & $\begin{array}{l}\text { Pelanggaran } \\
\text { komitmen }\end{array}$ & - & + & + & + & - & + & - \\
\hline 6 & Keuangan & - & - & + & - & - & + & - \\
\hline
\end{tabular}


Edutech, Tahun 12, Vol.1, No.3, Oktober 2013

\begin{tabular}{|c|l|c|c|c|c|c|c|c|}
\hline 7 & Perbedaan derajat & - & - & - & + & - & + & - \\
\hline 8 & $\begin{array}{l}\text { Intensitas } \\
\text { komunikasi }\end{array}$ & - & - & - & - & + & + & + \\
\hline 9 & Intensitas bertemu & - & + & - & - & + & + & - \\
\hline 10 & Ketakutan berlebihan & - & - & - & - & + & - & + \\
\hline 11 & Tuntutan meningkat & - & + & + & + & + & + & + \\
\hline
\end{tabular}

b. Penyesuaian dengan Suami dan Kondisi

Tabel Upaya Penyesuaian dalam Mut'ah

\begin{tabular}{|c|c|c|c|c|c|c|c|c|}
\hline \multirow[t]{2}{*}{ No } & \multirow{2}{*}{$\begin{array}{l}\text { Bentuk Upaya } \\
\text { Penyesuaian }\end{array}$} & \multicolumn{7}{|c|}{ Informan } \\
\hline & & $\begin{array}{c}\text { Bula } \\
\mathrm{n}\end{array}$ & $\begin{array}{l}\text { Bin- } \\
\text { tang }\end{array}$ & $\begin{array}{c}\text { Pelan } \\
\text { gi }\end{array}$ & $\begin{array}{c}\text { Maw } \\
\text { ar }\end{array}$ & $\begin{array}{l}\text { Melat } \\
\text { i }\end{array}$ & $\begin{array}{l}\text { Mata- } \\
\text { hari }\end{array}$ & $\begin{array}{l}\text { Anye } \\
\text {-lir }\end{array}$ \\
\hline 1 & $\begin{array}{l}\text { Pertemuan yang } \\
\text { lebih intens }\end{array}$ & - & - & + & + & + & + & + \\
\hline 2 & $\begin{array}{l}\text { Komunikasi yang } \\
\text { berkualitas }\end{array}$ & - & - & - & - & + & + & + \\
\hline 3 & $\begin{array}{l}\text { Hubungan intim } \\
\text { yang terkontrol }\end{array}$ & - & - & + & + & + & + & + \\
\hline 4 & $\begin{array}{l}\text { Keuangan sesuai } \\
\text { kemampuan }\end{array}$ & - & - & + & - & - & + & - \\
\hline 5 & $\begin{array}{l}\text { Kontrol sikap } \\
\text { terhadap keluarga }\end{array}$ & + & + & + & + & + & + & + \\
\hline 6 & $\begin{array}{l}\text { Kontrol sikap } \\
\text { kepada teman }\end{array}$ & + & + & + & + & + & + & + \\
\hline 7 & $\begin{array}{l}\text { Saling memahami } \\
\text { karakter }\end{array}$ & + & + & + & + & + & + & + \\
\hline
\end{tabular}

c. Pola Kerjasama

Tabel Pola Pemberian Nafkah Mut'ah

\begin{tabular}{|c|c|c|c|c|c|c|c|c|}
\hline No & Pola & \multicolumn{9}{|c|}{ Informan } \\
\cline { 3 - 9 } & PemberianNafkah & Bula & Bin- & Pelan & Maw & Melat & Mata- & Anye \\
& & n & tang & gi & ar & i & hari & - lir \\
\hline 1 & Suami beri nafkah & - & + & + & - & - & + & - \\
\hline
\end{tabular}




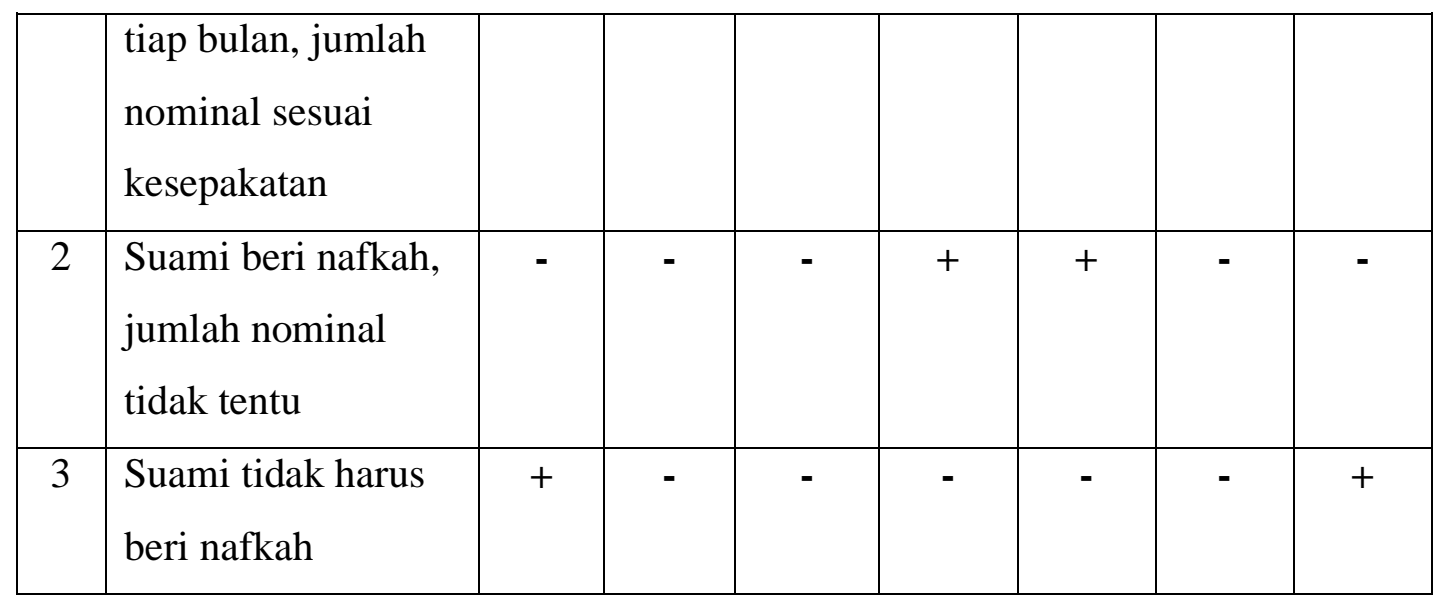

Tabel Pola Pemberian Dukungan pada Mut'ah

\begin{tabular}{|c|l|c|c|c|c|c|c|c|}
\hline No & \multicolumn{1}{|c|}{$\begin{array}{c}\text { Pemberian } \\
\text { Dukungan }\end{array}$} & \multicolumn{1}{|c|}{ Informan } \\
\cline { 2 - 9 } & $\begin{array}{l}\text { Bula } \\
\mathrm{n}\end{array}$ & $\begin{array}{c}\text { Bin- } \\
\text { tang }\end{array}$ & $\begin{array}{c}\text { Pelan } \\
\text { gi }\end{array}$ & $\begin{array}{c}\text { Maw } \\
\text { ar }\end{array}$ & $\begin{array}{c}\text { Melat } \\
\text { i }\end{array}$ & $\begin{array}{c}\text { Mata- } \\
\text { hari }\end{array}$ & $\begin{array}{c}\text { Anye } \\
- \text { lir }\end{array}$ \\
\hline $\begin{array}{l}\text { Pemberian } \\
\text { dukungan dalam } \\
\text { perkuliahan }\end{array}$ & + & + & - & - & - & - & - \\
\hline 2 & $\begin{array}{l}\text { Pemberian } \\
\text { dukungan dalam } \\
\text { karir }\end{array}$ & - & + & + & + & + & + & + \\
\hline 3 & $\begin{array}{l}\text { Berbagi wacana } \\
\text { ajaran Syiah }\end{array}$ & + & + & - & - & + & - & + \\
\hline
\end{tabular}

\section{d. Aktifitas Dramaturgis}

\section{dalam Nikah Mut'ah}

Para pelaku $m u t$ 'ah yang tidak mau memperoleh stigma buruk sebagai akibat dari mut'ah yang dilakukannya, akan menunjukkan gambaran diri yang dapat diterima masyarakat sekitar, yakni kesan tidak menikah mut'ah. Goffman (dalam

Mulyana,2004) mengasumsikan bahwa ketika orang-orang berinteraksi, mereka ingin menyajikan suatu gambaran diri yang akan diterima orang lain. Ia menyebut upaya itu sebagai "pengelolaan kesan", yaitu teknikteknik yang digunakan aktor untuk memupuk kesan-kesan tertentu dalam situasi tertentu untuk mencapai tujuan tertentu. Dalam 
presentasi dirinya pelaku mut'ah dengan tampilan diri yang akan menampilkan dirinya sesuai diinginkan.

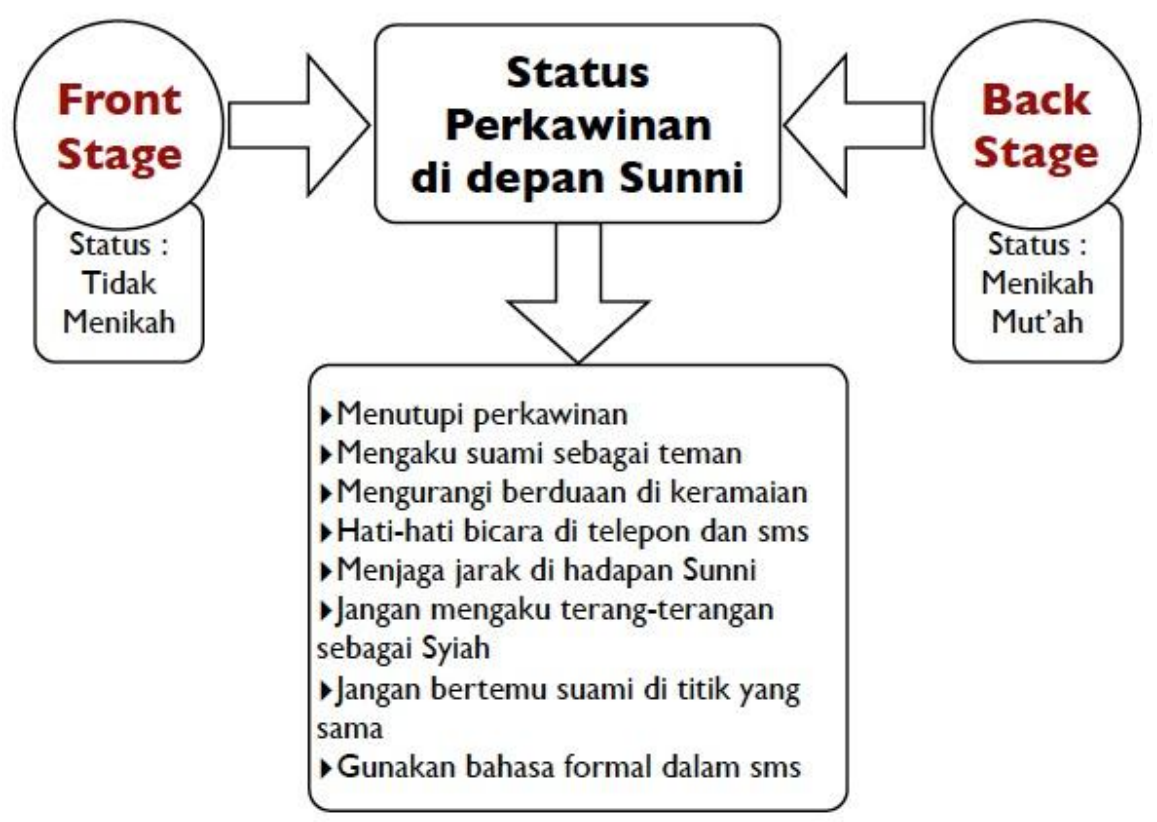

Gambar 11. Pengelolaan Pernyataan Status Perkawinan Mut'ah

\section{e. Status Tidak Menikah.}

Merupakan status atau keadaan yang ditunjukkan pada kalangan Sunni (front stage) . Ini merupakan upaya pengelolaan kesan untuk memperoleh kesan yang diinginkan yang diterima masyarakat, yaknin status tidak bermut'ah. Status yang diperankan para informan ketika berada di hadapan masyarakat Sunni adalah sebagai wanita tanpa suami (wanita single).

$$
\text { Hampir semua informan }
$$
memiliki kemampuan untuk memerankan peran ini. Segala perkataan, sikap, tindakan, dan pikiran diupayakan mengesankan seorang wanita tidak menikah . Bahkan juga berupaya mengesankan seorang penganut Sunni di hadapan orang Sunni. Dengan demikian para pelaku mut'ah dapat berinteraksi dengan lingkungan Sunni.

Pada informan yang sudah terlanjur diketahui masyarakat Sunni mengenai keberadaan suami mut'ahnya, mereka mengungkapkan suaminya sebagai teman dekat (kekasih). Bahkan pada informan Mawar yang

171 Perilaku Komunikasi Wanita Syiah dalam Pernikahan Mut'ah 
Edutech, Tahun 12, Vol.1, No.3, Oktober 2013

mut'ah berkali-kali dengan suami berbeda, selalu mengesankan suaminya sebagai teman biasa kepada teman Sunninya.

Kesan menutupi mut'ah juga tampak pada upaya mengurangi berduaan di tempat ramai, hati-hati dalam berkomunikasi di telpon genggam, serta sebisa mungkin menghindari bertemu teman Sunni ketika sedang bersama suami.

\section{f. Status Menikah Mut'ah}

Status ini merupakan status yang disembunyikan informan di hadapan kalangan Sunni. Sedapat mungkin jangan sampai mut'ah mereka diketahui Sunni.
Mereka lebih memilih bermain peran seolah tidak menikah di depan Sunni, meski ada perasaan yang mengganjal karena mereka tidak dapat menunjukkan keadaan yang sebenarnya di muka umum. Tetapi biar bagaimanapun ini merupakan pilihan terbaik. Karena jika temanteman mereka mengetahui mereka bermut'ah, maka konsekuwensinya mereka akan dikecam, dihina, direndahkan dan dijauhi temanteman.

\section{Manfaat mut'ah bagi pelaku}

Tabel Hal yang Menyenangkan dalam Mut'ah

\begin{tabular}{|c|l|c|c|c|c|c|c|c|}
\hline No & \multicolumn{1}{|c|}{$\begin{array}{c}\text { Pemberian } \\
\text { Dukungan }\end{array}$} & \multicolumn{1}{|c|}{ Informan } \\
\cline { 2 - 9 } & $\begin{array}{c}\text { Bula } \\
\mathrm{n}\end{array}$ & $\begin{array}{c}\text { Bin- } \\
\text { tang }\end{array}$ & $\begin{array}{c}\text { Pelan } \\
\text { gi }\end{array}$ & $\begin{array}{c}\text { Maw } \\
\text { ar }\end{array}$ & $\begin{array}{c}\text { Melat } \\
\text { i }\end{array}$ & $\begin{array}{c}\text { Mata- } \\
\text { hari }\end{array}$ & $\begin{array}{c}\text { Anye } \\
\text {-lir }\end{array}$ \\
\hline 2 & $\begin{array}{l}\text { Ketika bertemu } \\
\text { sangat romantis } \\
\text { Ketika berjauhan } \\
\text { merupakan } \\
\text { kesempatan untuk } \\
\text { produktif }\end{array}$ & + & + & + & + & + & + & + \\
\hline 3 & $\begin{array}{l}\text { Tidak terbebani } \\
\text { dengan kewajiban } \\
\text { melayani suami }\end{array}$ & + & + & + & + & + & + & + \\
\hline
\end{tabular}


2. Interaksi Dan Perilaku Syiah dan dengan Sunni, serta pada

\section{Komunikasi Nikah Mut'ah}

Dalam penelitian ini interaksi dan perilaku komunikasi dibedakan ke dalam 4 kategori, yaitu interaksi dan perilaku komunikasi pada mut'ah poligami dan monogami, tanpa hubungan intim, pada mut'ah dengan dalam model sebagai berikut:

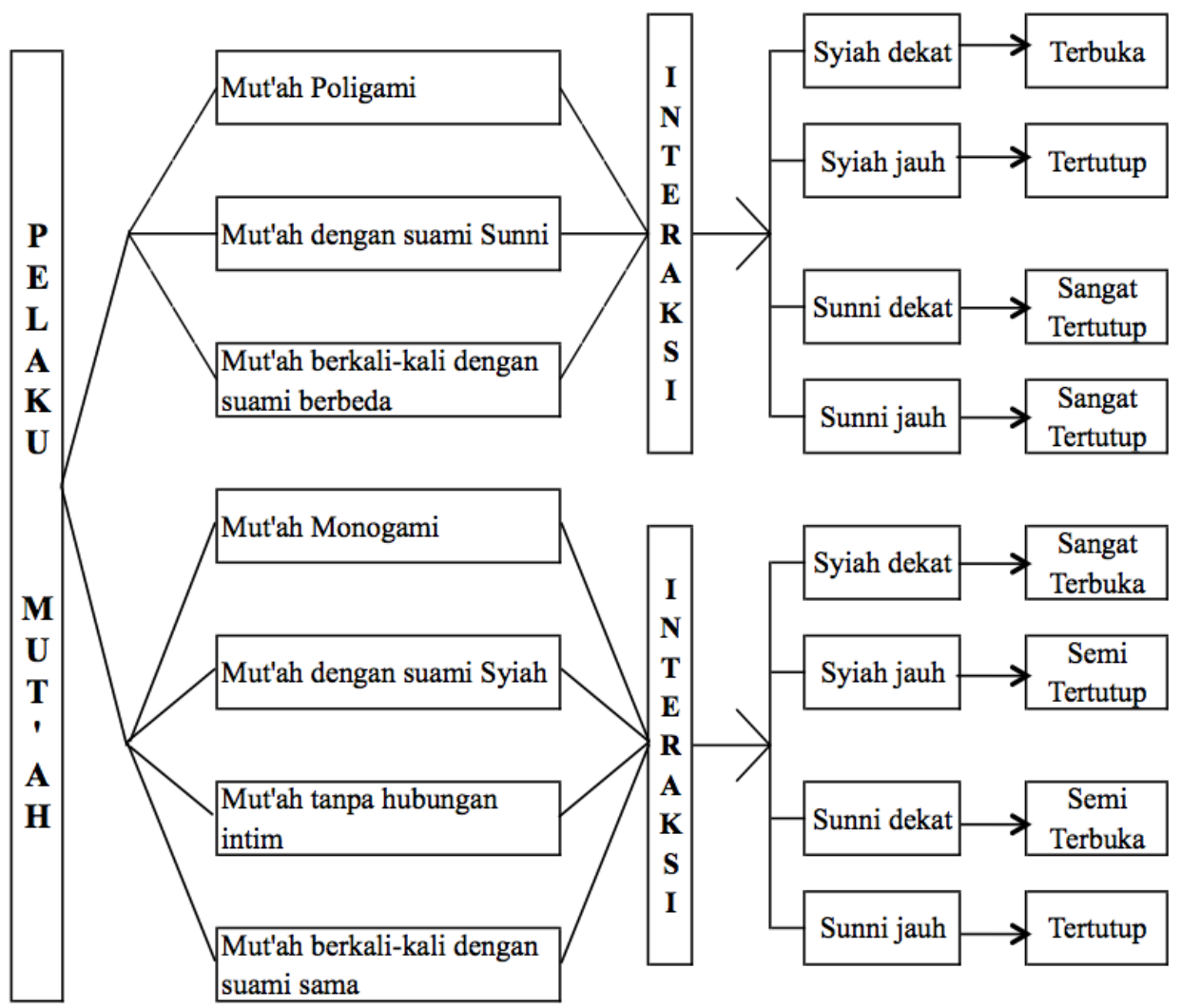

Gambar Model Perilaku Komunikasi Pelaku Mut'ah dengan Lingkungan.

(Sumber : Hasil Penelitian, 2013)

Model diatas dapat dijelaskan berbeda cenderung berinteraksi tertutup sebagai berikut: dengan lingkungan. Mereka

Pertama, pelaku mut'ah berinteraksi terbuka hanya dengan poligami, mut'ah dengan suami Sunni, teman Syiah yang benar-benar dekat. mut'ah berkali-kali dengan suami Interaksi tertutup ini karena, pertama, 
adanya kelhawatiran status pernikahan mut'ah mereka terbongkar oleh teman Sunni yang mengecam. Kedua, adanya amanah untuk berperilaku tidak sembarangan di muka umum demi menjaga nama baik kaum Syiah. , Adanya ketidaksiapan mental jika pernikahan diketahui Sunni nama baik mereka akan terancam. ,Keempat, Adanya keinginan dan kebutuhan untuk tetap bergaul dan diterima dengan baik di lingkunan masyarakat Sunni.

Kedua, pelaku mut'ah monogami, mut'ah dengan suami Syiah, Mut'ah tanpa hubungan intim, mut'ah berkali-kali dengan suami yang sama cenderung berinteraksi relatif terbuka untuk Syiah dekat dan Sunni dekat. Tetapi dengan Syiah jauh dan Sunni jauh cenderung berinteraksi tertutup. Sama halnya dengan mut'ah poligami, ketertutupan ini penyebabnya adalah semata mata khawatir status pernikahan mut'ahnya diketahui Sunni. Maka supaya interaksi dengan kalangan Sunni masih terjalin mereka harus menutupi status pernikahan mut'ahnya. Upaya menutupi mut'ah ini dengan cara menampilkan peran seolah mereka tidak menikah, tetapi hanya sebatas berteman saja.

Selanjutnya, tipologi perilaku komunikasi para pelaku nikah mut'ah dengan suami dalam berbagai kategori, dapat dilihat pada model sebagai berikut : 


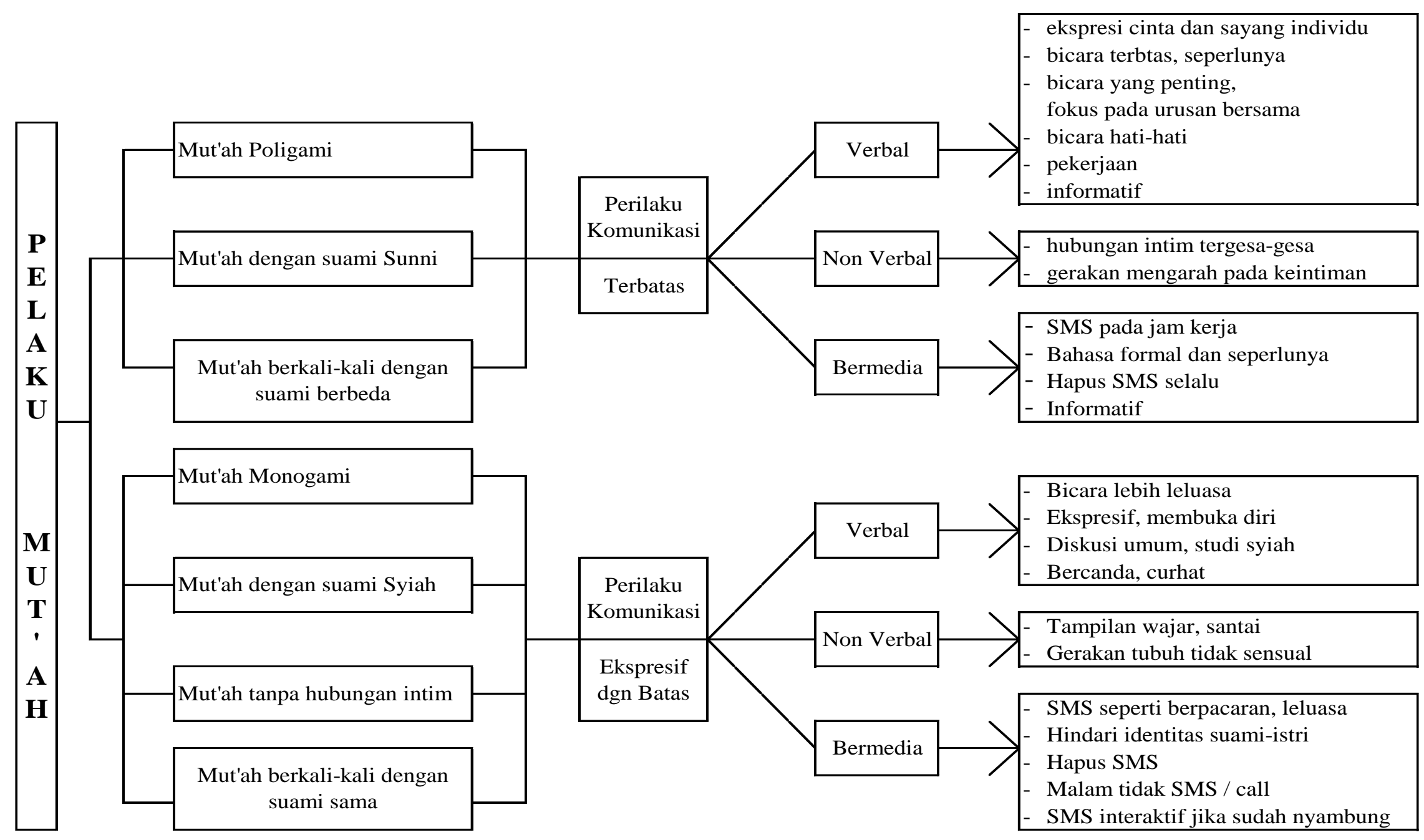

Gambar 6.9. Model Perilaku Komunikasi Pelaku Mut'ah dengan Suami. (Sumber : Hasil Penelitian, 2013) 
Model di atas bisa dijelaskan sebagai berikut:

Pertama, Para pelaku mut'ah poligami, mut'ah dengan suami Sunni, dan mut'ah berkali-kali dengan suami berbeda memiliki kecenderungan perilaku komunikasi yang terbatas, baik kualitas maupun kwantitas komunikasi. Komunikasi yang terjadi hanya berlangsung siang hari pada saat jam kerja, yakni dari jam 08.00 sampai sore sekitar jam 04.00. Dalam rentang waktu jam kerja ini, hanya ketika pekerjaan sedang senggang atau pada saat istirahat memungkinkan untuk berkomunikasi.

Komunikasi

berlangsung dalam durasi yang sangat singkat dengan melalui media handphone . Komunikasi langsung tanpa media berlangsung pada saat jam pulang kerja. Komunikasi langsung ini tidak berlangsung tiap hari. Jika jam sibuk atau lembur mereka tidak ada waktu untuk bertemu. Pada dasarnya komunikasi yang sangat terbatas ini karena: pertama, mereka tidak tinggal serumah. Kedua, kesibukan pada ke dua belah pihak tidak memungkinkan mereka bisa bertemu. Ketiga, adanya aspek kehati-hatian pada keduanya, mereka khawatir pernikahan mereka diketahui keluarga dan lingkungan Sunni.

Kedua, Pelaku mut'ah monogami, mut'ah dengan suami Syiah, mut'ah tanpa hubungan intim, dan mut'ah berkali-kali dengan suami yang sama memiliki kecenderungan perilaku komunikasi yang relatif lebih terbuka meski masih dalam keterbatasan. Terbuka dalam arti lebih bebas mengekspresikan komunikasi dalam waktu yang relatif leluasa ketimbang pelaku mut'ah poligami. Penggunaan media agak jarang. Mereka lebih sering berkomunikasi langsung secara verbal maupun nonverbal. Keleluasaan berkomunikasi ini karena: pertama, tidak ada rasa ketakutan secara berlebihan oleh keluarga, karena status mereka single (kecuali pelaku dengan suami Syiah). Kedua, status mereka yang masih kuliah memungkinkan mereka untuk bertemu lebih intens. Ketiga, pembicaraan jarang menyerempet halhal romantis, lebih cenderung masalah umum.

\section{SIMPULAN}

\section{Kesimpulan}

Berdasarkan hasil penelitian dan pembahasan tentang perilaku komunikasi para wanita Syiah 
Edutech, Tahun 12, Vol.1, No.3, Oktober 2013

pelaku nikah mut'ah di Kota Bandung, maka dapat ditarik beberapa kesimpulan sebagai berikut :

a. Pelaksanaan mut'ah wanita Syiah di Kota Bandung dapat diuraikan dalam beberapa aspek, yaitu:

Fakta besarnya potensi konflik dalam mut'ah.

Penyesuaian dengan suami dan lingkungan yang adaptif,

Pola kerja sama sesuai kesepakatan yang akomodatif,

Sikap dramaturgis yang aman dari kecurigaan Sunni.

b. Perilaku komunikasi wanita Syiah pelaku nikah mut'ah di Kota Bandung dapat djelaskan dari tiga aspek yaitu :

Pertama, Pada pelaku mut'ah poligami, mut'ah suami Sunni, dan mut'ah berkali-kali dengan suami yang berbeda; perilaku komunikasi verbal cenderung hati-hati, komunikasi non verbal terbatas, dan komunikasi bermedia seperlunya.
Sementara pada mut'ah monogami, mut'ah tanpa hubungan intim, mut'ah dengan suami Syi'ah, mut'ah berkalikali dengan suami yang sama; komunikasi verbal lebih ekspresif, komunikasi non verbal wajar, dan komunikasi bermedia leluasa.

Kedua, Pada aspek interaksi dengan lingkungan pelaku mut'ah poligami, mut'ah dengan suami Sunni, mut'ah berkali-kali dengan suami yang berbeda; bersikap terbuka kepada Syiah dekat, tertutup kepada Syiah Jauh, sangat tertutup kepada Sunni dekat, dan sangat tertutup kepada Sunni jauh. Sementara pada pelaku mut'ah monogami, mut'ah tanpa hubungan intim, mut'ah dengan suami Syiah, dan mut'ah berkali-kali dengan suami yang sama; bersikap sangat terbuka kepada Syiah dekat, semi tertutup kepada Syiah jauh, semi terbuka kepada Sunni dekat, dan tertutup kepada Sunni jauh.

Ketiga, Sikap dramaturgis di hadapan masyarakat Sunni dan 
Edutech, Tahun 12, Vol.1, No.3, Oktober 2013

sikap dewasa dalam menjalani pernikahan mut'ah, merupakan konsekuensi dari pernikahan yang telah mereka pilih sebagai alternatif pernikahan.

\section{Saran}

Saran-saran yang $r$ dapat
dikemukakan sesuai dengan hasil
penelitian yang telah dilakukan untuk
dapat menjadi pertimbangan berbagai
pihak, baik dalam kaitannya dengan
pengembangan keilmuan maupun
dalam upaya memberikan kontribusi
dalam menyikapi r kelompok
masyarakat yang memiliki keyakinan
non-mainstream adalah
berikut:

a. Saran Teoritis

1) Penelitian mengenai perkawinan, khususnya mengenai praktek perkawinan mut'ah yang kontroversil ini masih sangat jarang dilakukan., oleh karena itu perlu dikembangkan penelitian tentang perkawinan ini terutama dengan menggunakan pendekatan subjektif, sehingga diperoleh temuan-temuan baru yang konstruktif dalam upaya memahami makna yang dipahami para pelaku mut'ah.

2) Penelitian dengan menggunakan pendekatan subjektif yang berorientasi pada sudut pandang pelaku mut'ah ini akan memberikan kontribusi pemikiran dalam memahami keyakinan para pelaku nikah mut'ah secara lebih jernih.

3) Penelitian tentang pernikahan mut'ah dalam skala yang lebih luas, bukan hanya dalam skope kecil tetapi merambah sampai ke seluruh wilayah Indonesia perlu dilakukan, hal ini sehubungan dengan pelaksanaan mut'ah yang sangat beragam disesuaikan dengan situasi dan kondisi setempat. Tentunya hasil penelitian yang diperoleh akan semakin memberikan pengayaan keilmuan baik di bidang Ilmu Komunikasi maupun Ilmu Sosial dan Budaya.

4) Seandainya memungkinkan, melakukan penelitian mut'ah dengan membandingkan mut'ah di Indonesia dengan mut'ah yang dipraktekkan di negara 
Edutech, Tahun 12, Vol.1, No.3, Oktober 2013

yang mayoritas syi'ah yaitu Iran. Hasil penelitian akan berguna dalam memperkaya khasanah ke-Islaman.

5) Mengungkapkan realitas dengan mengkaji secara intensif fenomena nikah mut'ah dengan pendekatan subjektif, diharapkan mampu menghadirkan kesadaran dan semangat toleransi pada masyarakat plural.

\section{b. Saran Praktis}

1) Bagi pemerintah dan pemimpin masyarakat, khususnya instansi terkait dalam hal ini Kementrian Agama serta MUI, hendaknya menyikapi komunitas Syiah (pelaku $\left.m u t^{\prime} a h\right)$ ini secara lebih empati dan kearifan. Dalam menentukan sikap dan pernyataan politik agar lebih berhati-hati, sehingga bentrokan klasik antar warga Syiah dan Sunni tidak terulang lagi.

2) Bagi para pelaku mut'ah ( kalangan Syiah), hendaknya lebih legowo, bersabar, dan menahan diri dalam menghadapi sikap masyarakat

$$
\begin{aligned}
& \text { Sunni yang apriori dan } \\
& \text { cenderung menyerang }
\end{aligned}
$$
kalangan Syiah sebagai kaum yang sesat. Sadarilah bahwa tindakan kekerasan meski dengan dalih mempertahankan diri tidak selamanya efektif.

3) Bagi masyarakat secara umum (kalangan Sunni), hendaknya jangan mudah terprovokasi dengan upaya-upaya yang mau mengobok-obok antara SunniSyiah. Tebarkanlah nafas pluralisme, toleransi serta budaya komunikasi yang saling menghargai antar keyakinan yang berbeda (Sunni vs Syiah).

\section{DAFTAR PUSTAKA}

\section{Buku Ilmiah :}

Beebe A Steve, Susan J Beebe \& Redmond V Mark. 2006. Interpersonal Communication (Relating to Other). London: Allyn \& Bacon.

Berger, Peter L \& Thomas Luckman. 1966. The Social Construction of Reality : A Treatise in the Sociology of Knowledge. New York: Anchor Books.

Bradshaw, John. 1998. The Family: A Revolutionary Way of Self- 
Edutech, Tahun 12, Vol.1, No.3, Oktober 2013

Discovery. Florida : Health

Communication, Inc.

Bulaeng, Andi, 2000. Metode

Penelitian

Komunikasi

Kontemporer.

Makassar:

Hasanuddin University Press.

Cangara, Hafied. 2003. Pengantar Ilmu

Komunikasi. Raja Grafindo

Persada. Jakarta.

Charon, Joel M. 1979. Symbolic

Interactionism. Prentice-Hall.

Inc., Englewood Cliffs N.J.

Craib, Ian. 1984. Teori - Teori Sosial

Modern : dari Parsons sampai

Habernas Jakarta : CV Rajawali.

Creswell, John W. 1994. Research

Design : Qualitative and

Quantitative Approaches.

Westport, CT: Praeger

Publishers.

Devito, A. Joseph. 1997. Komunikasi

Antar Manusia. Jakarta:

Professional Books.

Fisher, Walter R. 1987. Human

Communication as Narration:

Toward a philoshopy of reason,

value and action. Columbia :

University of California Press.

Ghozally, R. Fitri. 2011. Resiko

Menikah. Jakarta: Arya Pustaka.

Hamdani, Muhammad Faisal. 2008.
Perbandingan Hukum Antara

Sunni \& Syiah. Jakarta: Gaya

Media Pratama.

Kuswarno, Engkus. 2009. Metodologi

Penelitian

Komunikasi

Fenomenologi

Konsepsi

Pedoman dan Contoh Penelitian.

Bandung: Widya Padjadjaran.

Littlejohn, Stephen W. 1996. Theories

of Human Communication (Fifth

Edition). New York: Wardsworth

Publishing Company.

Moleong, Lexy J. 2009. Metodologi

Penelitian Kualitatif. Bandung:

Remaja Rosdakarya.

Moustakas, $\quad$ Clark. 1994.

Phenomenological Research

Methods. USA: Sage.

Mulyana, Deddy. 1999. Nuansa-

Nuansa Komunikasi. Bandung:

Rosdakarya.

2004. Metodologi

Penelitian Kualitatif. Bandung :

Remaja Rosdakarya.

2007. Ilmu

Komunikasi Suatu Pengantar.

Bandung: Remaja Rosdakarya.

Efektif (Suatu Pendekatan

Lintasbudaya). Bandung:

Rosdakarya.

Nikah Mut'ah Analisis

180 Perilaku Komunikasi Wanita Syiah dalam Pernikahan Mut'ah 
Edutech, Tahun 12, Vol.1, No.3, Oktober 2013

2008. Metodologi

Penelitian Kualitatif (Paradigma

Baru Ilmu Komunikasi dan Ilmu

Sosial Lainnya). Bandung:

Remaja Rosdakarya. . 2010. Komunikasi

Lintas Budaya, Pemikiran,

Perjalanan \& Khayalan.

Bandung : Remaja Rosdakarya. \& Solatun. 2007.

Metode Penelitian Komunikasi :

Contoh-Contoh Penelitian

Kualitatif dengan Pendekatan

Praktis. Bandung : Remaja

Rosdakarya.

Mustafa, Ibnu. 1999. Perkawinan

Mut'ah dalam Perspektif Hadis

dan Tujuan Masa KIni. Jakarta :

Lentera.

Nurhadi, Dadi. 2003. Nikah di Bawah

Tangan: Praktik Nikah sirri

Mahasiswa Jogja. Yogyakarta:

Saujana.

Pieloor, Freddy. 2011. Money, Love \&

Mariage. Jakarta : Gramedia.

Rakhmat, Jalaluddin. 2000. Metode

Penelitian Komunikasi. Remaja

Rosdakarya, Bandung . 2000. Psikologi

Komunikasi. Bandung: Remaja

Rosdakarya.
2004. Psikologi

Komunikasi. Bandung : CV.

Remaja Rosdakarya.

Rusydi, Teuku Edy Faisal. 2007.

Pengesahan Kawin Kontrak

Pandangan Sunni \&

Syi'ah.Yogyajarta: Pilar Media.

Santoso, Edi dan Mite Setiasah. 2010.

Teori Komunikasi. Yogyakarta:

Graha Ilmu.

Saujana, Dadi Nurhaedi. 2003. Nikah

di Bawah Tangan Praktik Nikah

Sirri Mahasiswa Jogja.

Yogyakarta: Percetakan Ar-Ruzz

Media.

Schutz, Alferd. 1967. The Phenomenology of the Social World. Evaston Illinois. Northwestern University Press.

1972. The

Phenomenology of The Social

World. USA : North Western

University Press.

Sendjaya, Sasa Djuarsa, 1993. Teori

Komuikasi. Jakarta: UT

Shadiq, Adil, 2009. Cinta Tanpa

Nikah, Nikah Tanpa Cinta.

Surakarta: Ziyad Visi Media.

Syam, Nina Winangsih. 2009.

Sosiologi Komunikasi. Bandung:

Humaniora. 
West, R., R., \& Turner, L. H. 2007. Nurlimah, Nila dan Khotimah, Ema. Introducing Communication 2011. Konstruksi Makna Nikah Theory: Analysis and Aplication. Mut'ah pada Kalangan Mayfield: Mountain View, CA. Mahasiswa di Bandung. LPPM, Wiryanto. 2005. Pengantar Ilmu Unisba.

Komunikasi. Jakarta: Gramedia Yuliati, Nova. 2010. Pemaknaan, Widiasarana Indonesia. Penyesuaian dan Komunikasi

Journal, Disertasi, Tesis, Media, Skripsi, dan Sumber lainnya : Astuti, Santi Indra. 2006. Fenomenologi: $\quad$ A Brief Introduction.

Nurbani. 2010. Disertasi. Komunikasi Perempuan dalam Ikatan "Kawin Kontrak". (Studi tentang Konstruksi Realitas Hidup Pelaku Kawin Kontrak di Puncak Jawa Barat). Universitas Padjadjaran, Bandung. dalam Perkawinan pada Dosen Perempuan (Studi Fenomenologi tentang Perkawinan pada Dosen Perempuan di Lingkungan Unisba). Program Pascasarjana, Universitas Padjadjaran.

Zaitun, Abdullah. 1999. Tesis. Praktek Perkawinan Nikah Mut'ah di Indonesia. (Studi Kasus Perkawinan Mut'ah di Jawa Barat). Universitas Indonesia, Depok. 